\title{
AA Amyloidosis Secondary to Primary Sjögren Syndrome: Can It Be Developed without Chronic Inflammation?
}

\author{
Soukaina Zaher ${ }^{1}$, Kawtar Nassar ${ }^{1}$, Ibtissam Razzouki², Meriem Regragui², Mehdi Karkouri², \\ Saadia Janani ${ }^{1}$ \\ ${ }^{1}$ Department of Rheumatology, University Hospital Center of Ibn Rochd, Hassan II-Casablanca University, Casablanca, Morocco \\ ${ }^{2}$ Department of Pathology, University Hospital Center of Ibn Rochd, Hassan II-Casablanca University, Casablanca, Morocco \\ Email: *soukaina.zaher@gmail.com
}

How to cite this paper: Zaher, S., Nassar, K., Razzouki, I., Regragui, M., Karkouri, M. and Janani, S. (2021) AA Amyloidosis Secondary to Primary Sjögren Syndrome: Can It Be Developed without Chronic Inflammation? Open Journal of Rheumatology and Autoimmune Diseases, 11, 29-35. https://doi.org/10.4236/ojra.2021.112004

Received: February 10, 2021

Accepted: April 19, 2021

Published: April 22, 2021

Copyright $\odot 2021$ by author(s) and Scientific Research Publishing Inc. This work is licensed under the Creative Commons Attribution International License (CC BY 4.0).

http://creativecommons.org/licenses/by/4.0/

\begin{abstract}
Background: The association of primary Sjögren syndrome (PSS) and AA amyloidosis is a rare occurrence. Objective: To describe the phenotype of patients with this association through our two cases and a literature review. Materials and methods: A report of two cases of AA amyloidosis complicating primary Sjögren syndrome with a literature review. Results: Eight patients of Primary Sjögren's Syndrome complicated by AA amyloidosis were studies. Six cases were reported in the literature by consulting several databases. $50 \%$ of patients had a positive immunological assessment, three cases with kidney damage, and three cases lung damage. Conclusion: The immunological activity in the Primary Sjogren's Syndrome requires the search not only a lymphoma but also AA amyloidosis apart from any clinical or biological chronic inflammation.
\end{abstract}

\section{Keywords}

AA Amyloidosis, Amyloid, Primary Sjögren Syndrome

\section{Introduction}

AA amyloidosis is a rare complication of chronic inflammatory rheumatism and exceptional in primary Sjögren syndrome (PSS). Primary Sjögren's syndrome is a rare systemic autoimmune disease, in which B cells play a central role in its pathogenesis [1]. In patients with PSS, the hypergammaglobulinemia and the presence of autoantibodies (rheumatoid factor, anti-Ro/SSA and anti-La/SSB) support the main function of B cells. Many hypotheses have linked the activation 
of these cells to both the risk of developing lymphoma and the risk of AA amyloidosis [2].

The objective of this article is to describe the phenotype of patients followed for primary Sjögren's syndrome complicated by AA amyloidosis, based on two cases reported and a review of the literature regarding this association.

\section{Material and Methods}

A retrospective review of the medical records of all patients with primary Sjögren's syndrome that presented to the rheumatology department at the Ibn Rochd University Hospital in Casablanca from January 2010 to June 2020 was conducted. The inclusion criteria were all patients over 16 years of age who had a diagnosis of primary Sjögren's syndrome confirmed histologically (sialadenitis stage 3 or 4) and/or immunologically (anti-Ro/SSA and/or anti-La/SSB) and complicated by AA amyloidosis, as confirmed by anatomopathological examination and immunohistochemistry. Patients less than 16 years of age, patients followed for Sjögren syndrome associated with other chronic inflammatory rheumatism, and those associated with AL amyloidosis were excluded. We conducted a literature review in several databases: PubMed, sciencedirect, embase, and scopus, since their creation until August 2020 as to obtain information on this complication. The keywords used were: AA amyloidosis, Sjögren.

\section{Results}

Two cases of primary Sjögren's syndrome complicated by AA amyloidosis were identified in the retrospective review conducted in our department for the period between January 2010 and August 2020, which are presented below. Six cases were found in the literature. All the cases are summarized in Table 1.

\section{Case 1}

A 54-year-old woman with a history of ocular, buccal and cutaneous dryness that has been evolving over the past year, associated with mechanical arthralgia, myalgia, generalized fatigue, skin hyperpigmentation and paroxysmal parotidomegaly. All this conditions occurred in a context of deterioration of general condition. The physical examination during hospitalization revealed joint pain involving the shoulders, diffuse skin pigmentation and a bluish spot on the right jugal side. Biologically, she had a normal blood count, negative inflammatory assessment (ESR at $21 \mathrm{~mm} / \mathrm{h}, \mathrm{CRP}$ at $2.4 \mathrm{mg} / \mathrm{L}$ ), positive antinuclear antibody (titer 1:640; speckled pattern), positive anti-Ro (SS-A) antibodies, normal muscle mass, serum protein electrophoresis $\mathrm{C} 3$ and $\mathrm{C} 4$ returned to normal. The ophthalmologic consultation revealed bilateral superficial punctate keratitis. Salivary gland biopsy showed a lymphoplasmacytic infiltrate of grade I according to Chisholm's classification with amyloid deposits identified by Congo Red staining (Figure 1(a)), which reveals apple-green birefringence consistent with amyloid deposition under polarized light (Figure 1(b)). The immunohistochemistry was consistent with an amyloid AA protein (Figure 1(c)). The renal, cardiac, neurological and pulmonary assessments were unremarkable. The patient was started 
Table 1. Demographic, clinical and paraclinical characteristics of the eight patients followed for primary Sjögren syndrome complicated by AA amyloidosis.

\begin{tabular}{|c|c|c|c|c|c|c|c|c|c|}
\hline 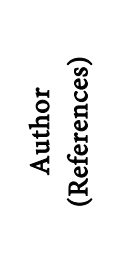 & 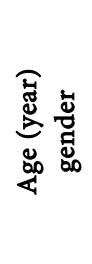 & 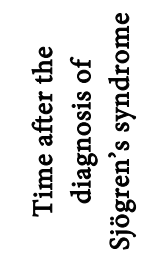 & 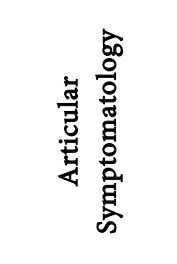 & 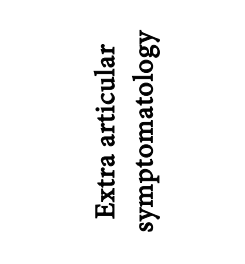 & $\begin{array}{l}\widehat{00} \\
0 \\
0 \\
\vdots \\
\vdots \\
\vdots \\
\vdots\end{array}$ & 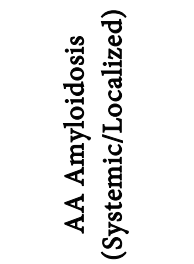 & 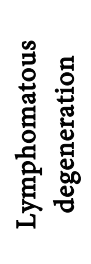 & 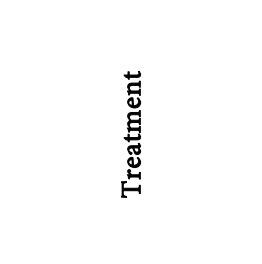 & 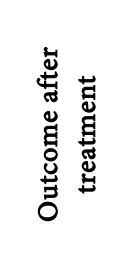 \\
\hline $\begin{array}{c}\text { Costa } \\
\text { et al. [3] }\end{array}$ & $\begin{array}{c}79 \\
\mathrm{~F}\end{array}$ & 22 days & NA & $\begin{array}{l}\text { Rapidly } \\
\text { progressive } \\
\text { renal failure } \\
\text { asthenia, } \\
\text { anorexia and } \\
\text { generalized } \\
\text { oedema }\end{array}$ & $\begin{array}{c}\text { ANA+ (1:80) } \\
\text { Anti-SSA+ } \\
(>200 \mathrm{UI} / \mathrm{ml}) \\
\text { Anti-SSB+ } \\
(40 \mathrm{U} / \mathrm{ml}) \\
\text { RF+ }(88.6 \mathrm{IU} / \mathrm{ml})\end{array}$ & Renal & No & $\begin{array}{l}\text { Corticosteroids } \\
\text { haemodialysis }\end{array}$ & Death \\
\hline $\begin{array}{l}\text { Motegi } \\
\text { et al. [4] }\end{array}$ & $\begin{array}{c}58 \\
\mathrm{~F}\end{array}$ & 8 years & NA & $\begin{array}{c}\text { Ocular, } \\
\text { buccal dryness }\end{array}$ & NA & Pulmonary & NA & NA & NA \\
\hline $\begin{array}{l}\text { Wong } \\
\text { et al. [5] }\end{array}$ & $\begin{array}{l}29 \\
\mathrm{~F}\end{array}$ & $\begin{array}{l}\text { At the time } \\
\text { of diagnosis }\end{array}$ & NA & NA & NA & Pulmonary & No & NA & NA \\
\hline $\begin{array}{l}\text { Parambil } \\
\text { et al. [6] }\end{array}$ & NA & NA & NA & Dyspnea & NA & Pulmonary & No & $\begin{array}{l}\text { Corticosteroids } \\
\text { Immunosuppression }\end{array}$ & NA \\
\hline $\begin{array}{l}\text { Ooms } \\
\text { et al. [9] }\end{array}$ & $\begin{array}{l}53 \\
M\end{array}$ & 18 years & NA & $\begin{array}{l}\text { Acute renal failure } \\
\text { and } \\
\text { nephrotic syndrome }\end{array}$ & NA & Renal & No & Corticosteroids & Favorable \\
\hline $\begin{array}{l}\text { Katsikas } \\
\text { et al. [7] }\end{array}$ & $\begin{array}{c}62 \\
\mathrm{~F}\end{array}$ & NA & Polyarthritis & $\begin{array}{c}\text { Mild mixed } \\
\text { sensory-motor } \\
\text { axonal } \\
\text { polyneuropathy }\end{array}$ & $\begin{array}{c}\text { ANA+ }(1: 640) \\
\text { Anti-SSA+ } \\
\text { Anti-SSB+ } \\
\text { RF+ } \\
(3600 \mathrm{IU} / \mathrm{ml})\end{array}$ & Cutaneous & No & $\begin{array}{l}\text { Corticosteroids } \\
\text { hydroxychloroquine }\end{array}$ & Favorable \\
\hline Case 1 & $\begin{array}{c}54 \\
\mathrm{~F}\end{array}$ & 1 year & $\begin{array}{l}\text { Mechanical } \\
\text { arthralgia }\end{array}$ & $\begin{array}{l}\text { Ocular, buccal } \\
\text { and cutaneous } \\
\text { dryness Myalgia, } \\
\text { generalized } \\
\text { fatigue, skin } \\
\text { hyperpigmentation } \\
\text { and paroxysmal } \\
\text { parotidomegaly }\end{array}$ & $\begin{array}{c}\text { ANA+ } \\
\text { Anti-SSA+ } \\
(200 \mathrm{IU} / \mathrm{ml}) \\
\text { Anti-SSB- }\end{array}$ & $\begin{array}{l}\text { Accessory Sali- } \\
\text { vary Glands }\end{array}$ & No & Rituximab & Favorable \\
\hline Case 2 & $\begin{array}{c}55 \\
\mathrm{~F}\end{array}$ & 6 years & $\begin{array}{l}\text { Inflammatory } \\
\text { arthralgia }\end{array}$ & Renal failure & $\begin{array}{c}\text { ANA+ } \\
\text { Anti-SSA+ } \\
\text { Anti-SSB-RF+ } \\
(252 \mathrm{IU} / \mathrm{ml})\end{array}$ & $\begin{array}{c}\text { Accessory } \\
\text { Salivary Glands } \\
\text { Renal } \\
\text { (inconclusive } \\
\text { biopsy) }\end{array}$ & No & $\begin{array}{c}\text { Rituximab } \\
\text { Corticosteroids }\end{array}$ & Stationary \\
\hline
\end{tabular}

F: female; M: male; ANA: antinuclear antibodies; RF: rheumatoid factor; NA: data not available.

on Hydroxychloroquine but was stopped after a month of use due to palpitations, then she was switched to Rituximab (course of $2 \mathrm{~g}: 1 \mathrm{~g}$ administered every 15 days) with a favorable response (ESSDAI-Fatigue).

Case 2

The patient is 55 years old and has no particular pathological history. She was hospitalized for a picture of chronic inflammatory polyarthralgia progressing 


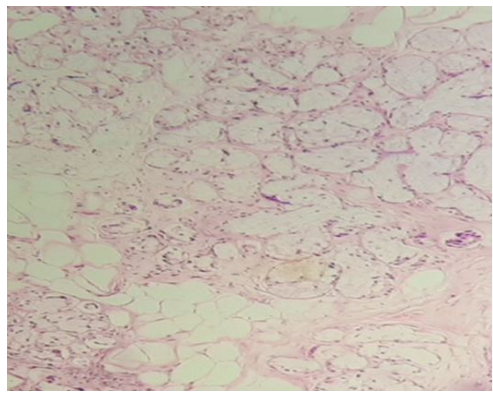

(a)

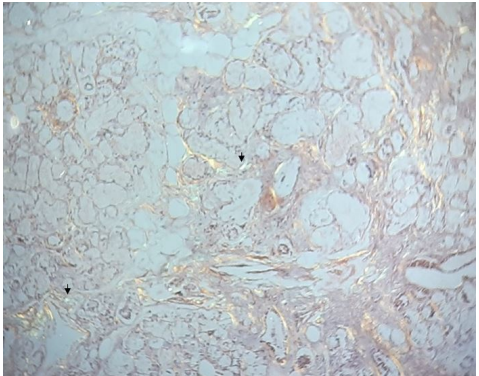

(b)

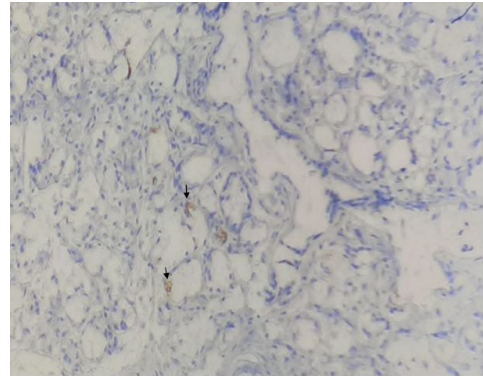

(c)

Figure 1. (a) Salivary glands biopsy showing a minimal eosinophilic deposits located along basement membranes and in the interstitium. Hematein eosin staining (HE $\times 100)$; (b) Apple-green birefringence character of amyloid deposits when viewed in polarized light. (Congo red stain $\times 100$ ); (c) Immunochemistry: Amyloid deposits strongly express the AA protein $(\times 40)$.

over 6 years associated with a subjective ocular and oral dryness. A bilateral superficial punctate keratitis was found in the assessment with positive anti-SSA and positive rheumatoid factors at $252 \mathrm{IU} / \mathrm{ml}$. Histological examination of salivary gland biopsy showed a lymphoplasmacytic infiltrate of grade I of Chisholm, the Congo Red stain demonstrate amyloid deposits (Figure 2(a)), with typical apple-green birefringence of amyloid deposition under polarized light (Figure 2(b)). The immunohistochemistry was consistent with an AA amyloid protein (Figure 2(c)). The assessment of renal function revealed renal failure with a glomerular filtration rate of $30 \mathrm{~mL} / \mathrm{min}$. Renal biopsy was performed but the results were inconclusive. Serum and urinary ionogram, and electrophoresis of serum proteins C3 and C4 were normal. Serology for hepatitis B and C was normal. Pulmonary function tests demonstrate a diffuse lung disease with non-septal thickening on the right side with nonspecific pattern and a slight decrease in the DLCO. Cardiovascular and neurologic examination findings were normal. Treatment with Rituximab has been proposed, which is not yet received and corticosteroids with a dose of $7.5 \mathrm{mg}$ per day with a stationary evolution.

\section{Discussion}

AA amyloidosis is a systemic acquired disease, characterized by the presence of extracellular tissue deposits of protein fibrils, and recognized by specific properties such as the green-yellow birefringence after Congo red staining, affecting all 


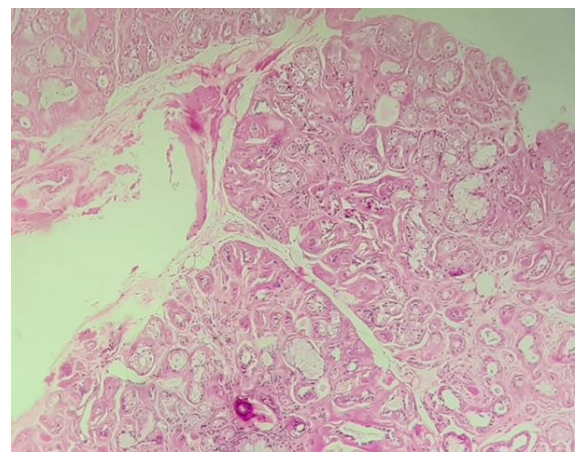

(a)

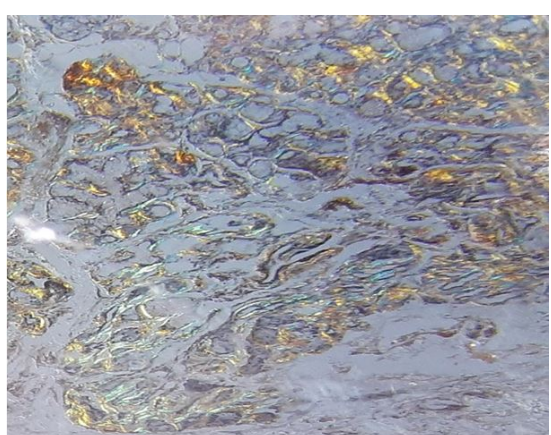

(b)

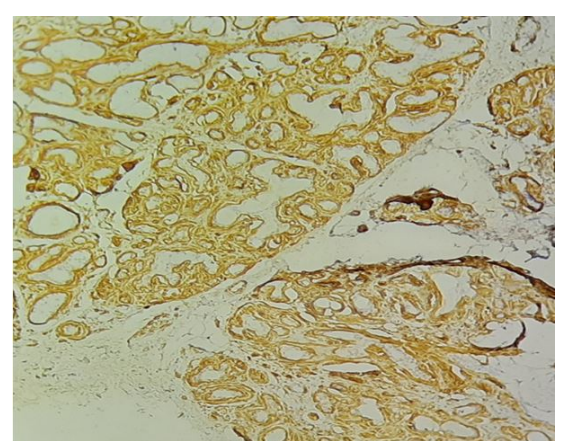

(c)

Figure 2. (a) Salivary glands biopsy showing eosinophilic deposits located along basement membranes and in the interstitium. Hematein eosin staining $(\mathrm{HE} \times 40)$; (b) Apple-green birefringence character of amyloid deposits when viewed in polarized light. (Congo red stain $\times 100$ ); (c) Immunochemistry: Amyloid deposits strongly express the AA protein $(\times 40)$.

organs except the central nervous system, and complicating any chronic inflammatory disease or infection [8]. AA amyloidosis rarely complicates PSS. The risk of developing AA amyloidosis is related to persistent subclinical inflammation and, therefore, to the degree and duration of elevated AA amyloid protein levels [9]. In our first case, the patient did not have a biological inflammatory syndrome, while the second case had a mild inflammatory syndrome. When associated to PSS, amyloidosis is diagnosed 1 to 25 years after the diagnosis of the disease, although in some cases they were diagnosed simultaneously. This may be the consequence of a delayed diagnosis of PSS in patients who previously had only mild symptoms related to the disease [10], which seems to be the case among these patients. Despite being a common complication of chronic inflammatory disease, few studies have evaluated the natural history, prognostic markers and treatment of AA amyloidosis [11]. The first known successful treatments for systemic amyloidosis were described in the context of AA amyloidosis. Amyloid deposits are derived from the proteolysis of serum amyloid A that mainly synthesized by the liver, and almost invariably affect the kidneys [12]. Studies on experimental murine AA amyloidosis show that AA amyloid can indeed be spontaneously eliminated when inflammation is stopped by redundant innate immune mechanisms [13] [14]. They also demonstrate that after 
apparent resolution of AA amyloid deposits, a relapse of inflammation can lead to a rapid and dramatic exacerbation of amyloid deposits, presumably due to residual AA amyloid fibrils that are resistant to compensatory mechanisms and serve as nucleator seeds, further emphasizing the importance of maintaining low serum amyloid A levels throughout the course of the disease [15]. 50\% of the reported cases of PSS complicated by AA amyloidosis had a high immunological activity (Positive serum anti-SSA/anti-SSB, positive rheumatoid factor). For the other cases, the serological profile was not specified, which agrees with Hernandz-molina et al. regarding the systematic search for amyloidosis in patients with consistently high serological activity with suggestive lesions [2].

\section{Conclusion}

The immunological activity in the Primary Sjogren's Syndrome requires the search not only a lymphoma but also AA amyloidosis apart from any clinical or biological chronic inflammation.

\section{Conflicts of Interest}

The authors declare that they have no competing interest.

\section{Ethics Approval and Consent to Participate}

The case report was approved by the Ethics Committee of the University Hospital of Ibn Rochd.

\section{Consent for Publication}

Patient's written consent was obtained.

\section{Availability of Data and Material}

Data concerning the patient's record are available from the corresponding author on reasonable request.

\section{Authors' Contributions}

SZ: conception, data curation, interpretation, and writing of the manuscript. KN, IR, MR, MK, SJ: conception, data curation, and supervision of the draft.

\section{References}

[1] Cornec, D., Devauchelle-Pensec, V., Tobon, G.J., et al. (2012) B Cells in Sjogren's Syndrome: From Pathophysiology to Diagnosis and Treatment. Journal of Autoimmunity, 39, 161-167. https://doi.org/10.1016/j.jaut.2012.05.014

[2] Hernandez-Molina, G., Faz-Munoz, D., Astudillo-Angel, M., Iturralde-Chavez, A. and Reyes, E. (2018) Coexistance of Amyloidosis and Primary Sjögren's Syndrome: An Overview. Current Rheumatology Reviews, 14, 231-238. https://doi.org/10.2174/1573397113666170103152537

[3] Costa, M., Greenfield, H., Pereira, R., Chuva, T., Henrique, R. and Cunha, C. (2019) 
A Rare Case of Renal AA Amyloidosis Secondary to Sjorgen's Syndrome. European Journal of Case Reports in Internal Medicine, 6. https://doi.org/10.12890/2019_001226

[4] Motegi, M., Suzuki, Y., Takayanagi, N., et al. (1994) A Case of Multiple Nodular Pulmonary Amyloidosis Associated with Sjogren's Syndrome. Nihon Kyobu Shikkan Gakkai Zasshi, 32, 1016-1021.

[5] Wong, B.C., Wong, K.L., Ip, M.S., et al. (1994) Sjogren's Syndrome with Amyloid A Presenting as Multiple Pulmonary Nodules. The Journal of Rheumatology, 21, 165-167.

[6] Parambil, J.G., Myers, J.L., Lindell, R.M., et al. (2006) Interstitial Lung Disease in Primary Sjogren's Syndrome. Chest, 130, 1489-1495.

https://doi.org/10.1378/chest.130.5.1489

[7] Katsikas, G.A., Maragou, M., Rontogianni, D., Gouma, P., Koutsouvelis, I., et al. (2008) Secondary Cutaneous Nodular AA Amyloidosis in a Patient with Primary Sjögren Syndrome and Celiac Disease. Journal of Clinical Rheumatology, 14, 27-29. https://doi.org/10.1097/RHU.0b013e318163815f

[8] Benson, M.D., Buxbaum, J.N., Eisenberg, D.S., Merlini, G., Saraiva, M.J.M., et al. (2018) Amyloid Nomenclature 2018: Recommendations by the International Society of Amyloidosis (ISA) Nomenclature Committee. Amyloid, 25, 215-219. https://doi.org/10.1080/13506129.2018.1549825

[9] Ooms, V., Decupere, M., Lerut, E., Vanrenterghem, Y. and Kuypers, D.R.J. (2005) Secondary Renal Amyloidosis Due to Long-Standing Tubulointerstitial Nephritis in a Patient with Sjögren Syndrome. American Journal of Kidney Diseases, 46, E75-E80. https://doi.org/10.1053/j.ajkd.2005.07.019

[10] Kweon, S.M., Koh, J.H., Lee, H.N., Kim, E., So, M.W., Shin, H.J., et al. (2018) Primary Sjogren Syndrome Diagnosed Simultaneously with Localized Amyloidosis of the Lacrimal Gland: A Case Report. Medicine (Baltimore), 97, e11014. https://doi.org/10.1097/MD.0000000000011014

[11] Yilmaz, M., Unsal, A., Sokmen, M., Kaptanogullari, O.H., Alkim, C., Kabukcuoglu, F., et al. (2013) Renal Involvement in AA Amyloidosis: Clinical Outcomes and Survival. Kidney and Blood Pressure Research, 37, 33-42. https://doi.org/10.1159/000343398

[12] Nevone, A., Merlini, G. and Nuvolone, M. (2020) Treating Protein Misfolding Diseases: Therapeutic Successes against Systemic Amyloidoses. Frontiers in Pharmacology, 11, 1024. https://doi.org/10.3389/fphar.2020.01024

[13] Nystrom, S.N. and Westermark, G.T. (2012) AA-Amyloid Is Cleared by Endogenous Immunological Mechanisms. Amyloid, 19, 138-145. https://doi.org/10.3109/13506129.2012.711391

[14] Sponarova, J., Nuvolone, M., Whicher, C., Frei, N., Kana, V., Schwarz, P., et al. (2013) Efficient Amyloid A Clearance in the Absence of Immunoglobulins and Complement Factors. The American Journal of Pathology, 182, 1297-1307. https://doi.org/10.1016/j.ajpath.2012.12.035

[15] Simons, J.P., Al-Shawi, R., Ellmerich, S., Speck, I., Aslam, S., Hutchinson, W.L., et al. (2013) Pathogenetic Mechanisms of Amyloid A Amyloidosis. Proceedings of the National Academy of Sciences of the United States of America, 110, 16115-16120. https://doi.org/10.1073/pnas.1306621110 